\title{
Pengaruh variabel-variabel di sektor riil dan perbankan terhadap Shock Credit Default Swap (CDS) di Indonesia
}

\section{${ }^{1}$ Dwi Hastuti*; ${ }^{2}$ Muhammad Edhie Purnawan; ${ }^{3}$ Sunargo}

\author{
${ }^{1}$ Fakultas Ekonomika dan Bisnis, Universitas Jambi, Indonesia \\ ${ }^{2}$ Fakultas Ekonomika dan Bisnis, Universitas Gadjah Mada, Indonesia \\ ${ }^{3}$ Fakultas Ekonomika dan Bisnis, Universitas Putra Batam, Indonesia \\ *E-mail korespondensi: dwihastuti@unja.ac.id
}

\begin{abstract}
The rapid development of the global financial market today is getting faster and integrated with the existence of advanced technology. Along with economic issues in various worlds, directly related to the global economic crisis that occurred in 20082009 greatly influenced the development of credit default swaps (CDS) in developing countries such as Indonesia. The increase in the value of the credit default swap, which carries a high risk of default, will further impact investor confidence and weaken the exchange rate. This is reflected in the shocks of the global crisis and the subprime mortgage prime in the United States. However, the onset of a global crisis can be early with early indicators of crisis from credit default swaps so that crisis management can be carried out faster. The results of this study indicate that the credit default swap is responded to faster by the banking sector than the real sector.
\end{abstract}

Keywords: Financial crises, Credit Default Swap (CDS), Riil and banking sector

\begin{abstract}
Abstrak
Perkembangan pesat pasar keuangan global di masa sekarang semakin cepat dan terintegrasi dengan adanya teknologi canggih. Seiring dengan isu perekonomian di berbagai dunia, terkait langsung dengan krisis ekonomi global yang terjadi tahun 2008-2009 sangat mempengaruhi perkembangan credit default swap (CDS) di negara sedang berkembang seperti Indonesia. Kenaikkan nilai credit default swap menggambarkan tingginya resiko gagal bayar (default) yang semakin tinggi, selanjutnya berdampak kepada kepercayaan investor dan melemahnya nilai tukar.Hal ini tergambar pada goncangan krisis global dan subprime mortgage prime di Amerika Serikat. Namun demikian adanya krisis global dapat diantisipasi lebih awal dengan indikator dini peringatan krisis dari credit default swap sehingga penanganan antisipasi krisis dapat dilakukan lebih cepat. Hasil penelitian ini menunjukkan bahwa credit default swap direspon lebih cepat oleh sektor perbankan dibandingkan dengan sektor riil.
\end{abstract}

Kata kunci: Krisis keuangan, Credit Default Swap (CDS), Sektor Riil dan Perbankan

\section{PENDAHULUAN}

Perkembangan teknologi yang canggih di masa sekarang menyebabkan pasar keuangan global semakin cepat dan terintegrasi. Hal ini menyebabkan dampak krisis keuangan global berpengaruh terhadap perekonomian suatu negara. Sehingga dapat dikatakan bahwa isu perekonomian di berbagai dunia terkait dengan pergerakan indikator pasar keuangan negara lain. Adanya dampak krisis keuangan global tercermin pada nilai credit default swap (CDS) yang tinggi. Nilai credit default swap (CDS) 
merupakan salah satu indikator yang digunakan untuk mendeteksi tingkat risiko investasi dan deteksi dini krisis global (Longstaff dan Mayer, 2009). Sementra itu, barometer kesehatan pasar keuangan ekonomi suatu negara dapat dilihat dari pergerakan indeks harga saham gabungan (Okky dan Setiawan, 2012).

Krisis ekonomi global yang terjadi di Amerika Serikat pada dekade tahun 20082009 sangat dipengaruhi perkembangan CDS di negara-negara berkembang termasuk di Indonesia. Secara umum, berdasarkan pada pergerakan CDS Indonesia tenor 5Y bergerak cukup volatil selama periode krisis 2008-2009, sehingga seorang JP Morgan Chase mengembangkan instrumen credit default swap (CDS), yang bertujuan untuk mentransfer risiko kredit di bank konvensional dengan pihak ketiga (Nomura Research, 2004). Ketika nilai CDS beberapa negara seperti Yunani, Portugal, Spanyol dan Indonesia bergerak naik hal ini, mengambarkan risiko bankrut atau gagal bayar (default) yang semakin tinggi dan berdampak pada melemahnya nilai mata uang yang kemudian berpengaruh terhadap pengurangan cadangan devisa atau terjadinya penurunan nilai mata uang lokal terhadap mata uang luar negeri (Golstein, et al. 2000). Dengan demikian, dapat disimpulkan bahwa credit default swap (CDS) sebagai indikator risiko kredit gagal bayar (default) suatu negara (Karlson dan Willebrand, 2009), dan Kajian awal IMF Report (2013).

Selanjutnya, adanya resesi menyebabkan menurunnya pendapatan dan komoditi dari negara-negara berkembang. Krisis ekonomi global yang terjadi di beberapa negara seperti Philipina, Thailand, Malaysia, dan Indonesia selama periode krisis 2008 mengalami kenaikan dibandingkan dengan sebelum terjadinya krisis (Gambar 1). Jika dibandingkan nilai credit default swap (CDS) beberapa negara tersebut, menunjukkan bahwa credit default swap (CDS) negara Indonesia lebih tinggi yaitu sebesar 709 bps pada 28 November 2008. Setelah itu, credit default swap (CDS) berturut-turut Philipina sebesar 473 bps pada 31Oktober 2008, Malaysia 296 bps pada 27 Februari 2009 dan Thailand sebesar 255 bps pada 31 Januari 2009 sebagai negara dengan level CDS terendah.

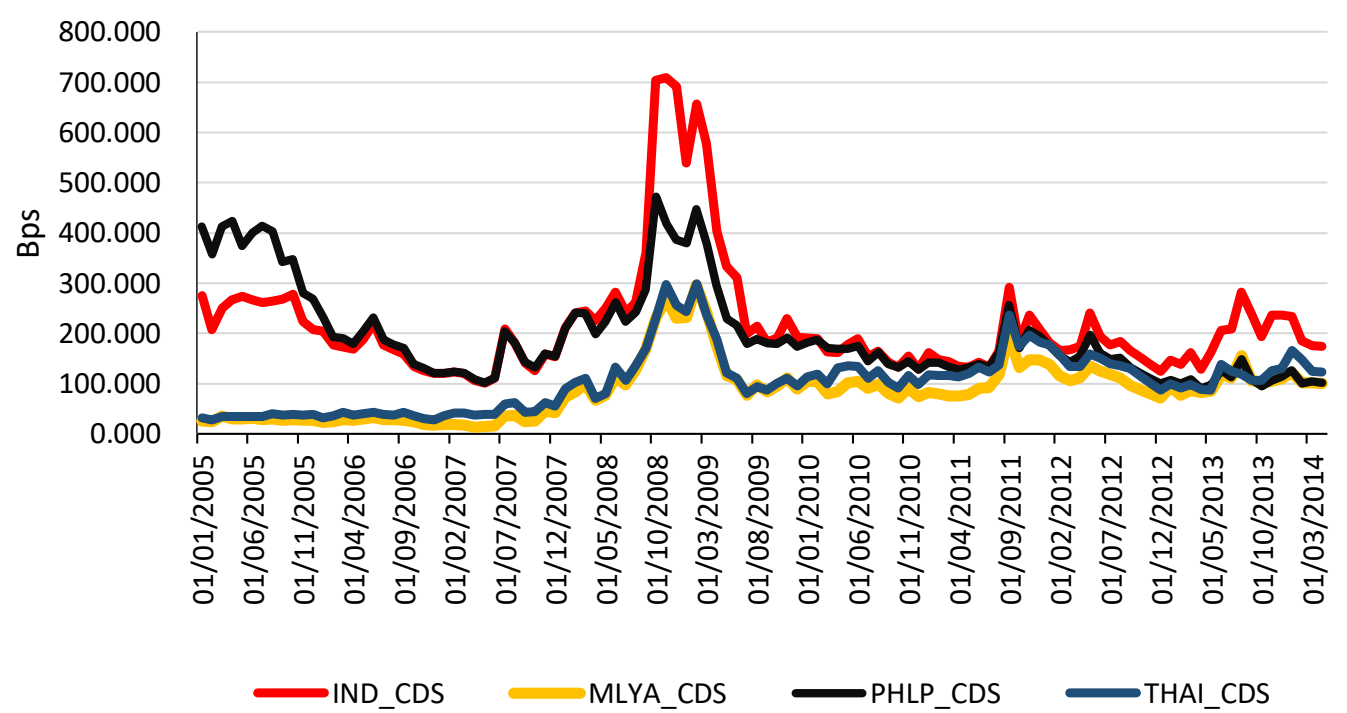

Gambar 1. Perbandingan Credit Default Swap (CDS) 5Y di Beberapa Negara Periode 2005:01-2014:12

Sumber: Bloomberg, 2015(diolah)

Sementara itu, pada akhir tahun 2009 hingga tahun 2011 CDS 5Y lebih stabil dengan spread yang lebih manageable dalam rentang 121-170 bps. Selama periode 
tahun 2008 credit default swap (CDS) mencapai 709 bps tertinggi dibandingkan dengan periode sebelumnya (Gambar 2).

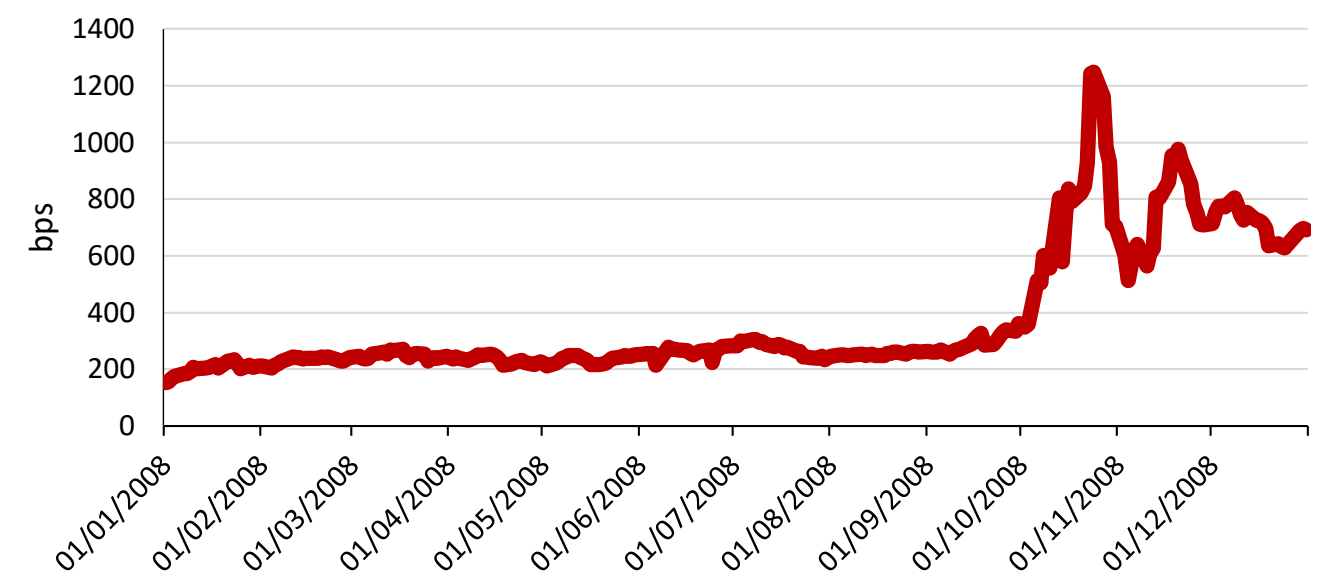

Gambar 2. Pergerakan Credit Default Swap (CDS) 5Y di Indonesia,Tahun 2008 Sumber: Bloomberg, 2015(diolah)

Penelitian yang dilakukan oleh Alexander dan Kaek (2007) menemukan bahwa interest rate, stock returns, dan implied volatility signifikan terhadap CDS spread. Sejalan penelitian Ginting dan Suwardi (2015) menunjukkan bahwa kenaikkan pada tingkat suku bunga dan inflasi maka yield to marturity (YTM) dalam suatu obligasi juga akan mengalami kenaikkan. Dengan demikian, ketika suku bunga berdampak positif terhadap perkembangan pasar modal, tentu saja, hal ini akan menjadi daya tarik bagi investor untuk berinvestasi di pasar modal (Tandelilin, 2001). Selanjutnya Karlson dan Willebrand (2009) menyatakan bahwa pada saat terjadinya krisis kredit, banyak bankbank besar yang mengalami gagal bayar (default) yang digambarkan pada indeks credit default swap (CDS), sehingga ketika nilai CDS tinggi dapat dikatakan bahwa risiko kredit suatu perusahaan tinggi.

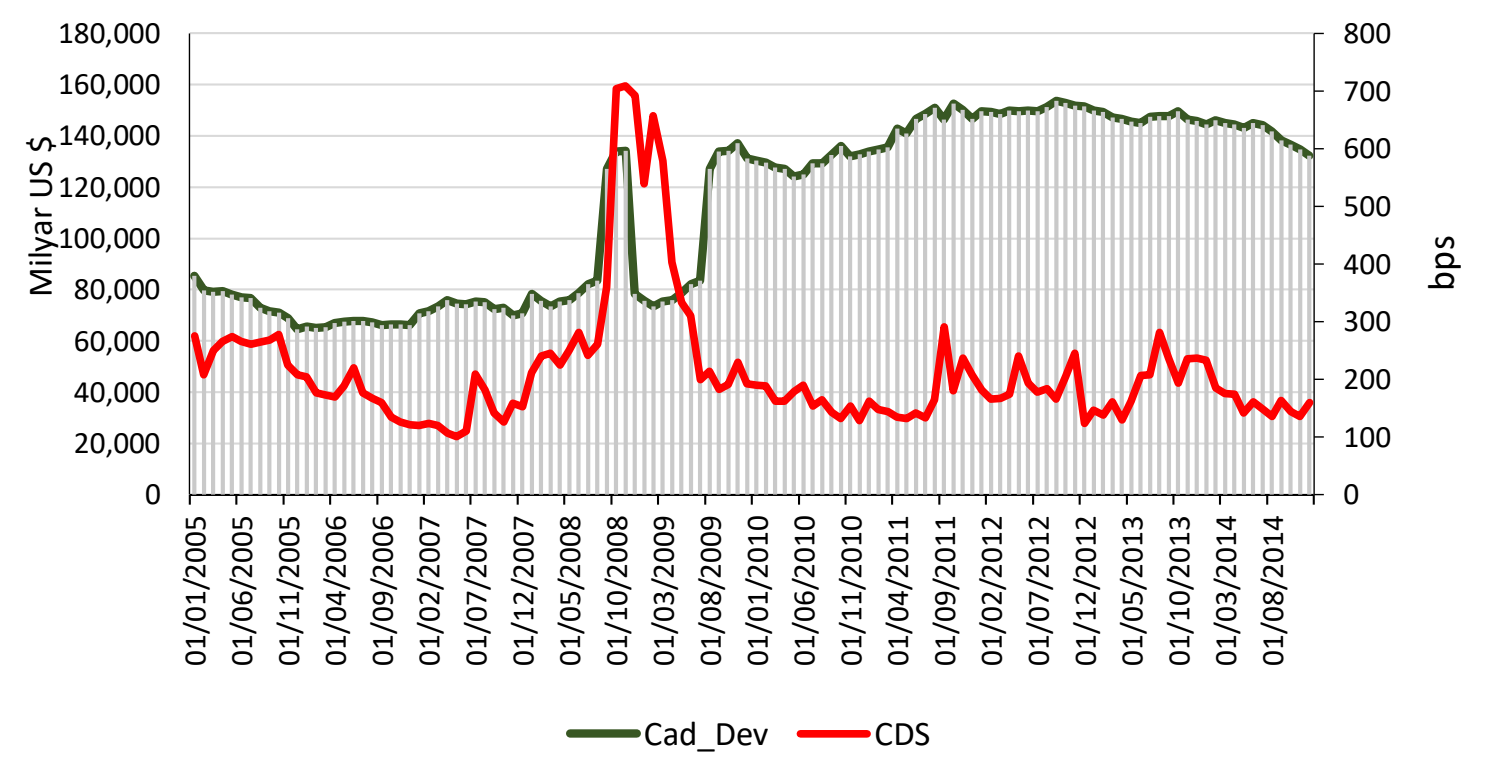

Gambar 3. Perkembangan Credit Default Swap (CDS) dan Cadangan Devisa, 2005:01-2014:12

Sumber: Bloomberg dan Bank Indonesia (BI), 2015(diolah) 
Kondisi ini sangat mempengaruhi cadangan devisa dan credit default swap (Gambar 3). Ketika krisis minyak tahun 2005 dan krisis global 2008-2009 pada bulan Februari dan Maret 2005 sebesar US \$ 79,780 miliar, turun 6,61\% dan US \$ 79.029 miliar, turun sekitar 0,94\%. Sementara sebelumnya pada bulan Januari 2005 sebesar US \$ 85,425 miliar. Kemudian pada 31 Desember 2008, di mana cadangan devisa telah menurun tajam dibandingkan tahun sebelumnya sebesar US \$ 134.266 menjadi US \$ 78,334 miliar atau 41,66\% dari penurunan. Gangguan perekonomian domestik ditandai dengan penurunan pertumbuhan PDB, cadangan devisa akan meningkatkan kemungkinan krisis ekonomi dan perbankan (Imansyah, 2009).

Penelitian Salvatore (1997) menunjukkan bahwa negara dengan kondisi ekonomi yang relatif baik digambarkan oleh pergerakan nilai tukar yang stabil. Sebaliknya pada saat kurs terdepresiasi tajam membuat utang berdenominasi mata uang asing yang dimiliki perusahaan menjadi berlipat-lipat dalam waktu singkat sehingga memperburuk neraca pembayaran di dalam negeri yang kemudian akan memperparah kondisi makro secara menyeluruh dan harga obligasi semakin tinggi.

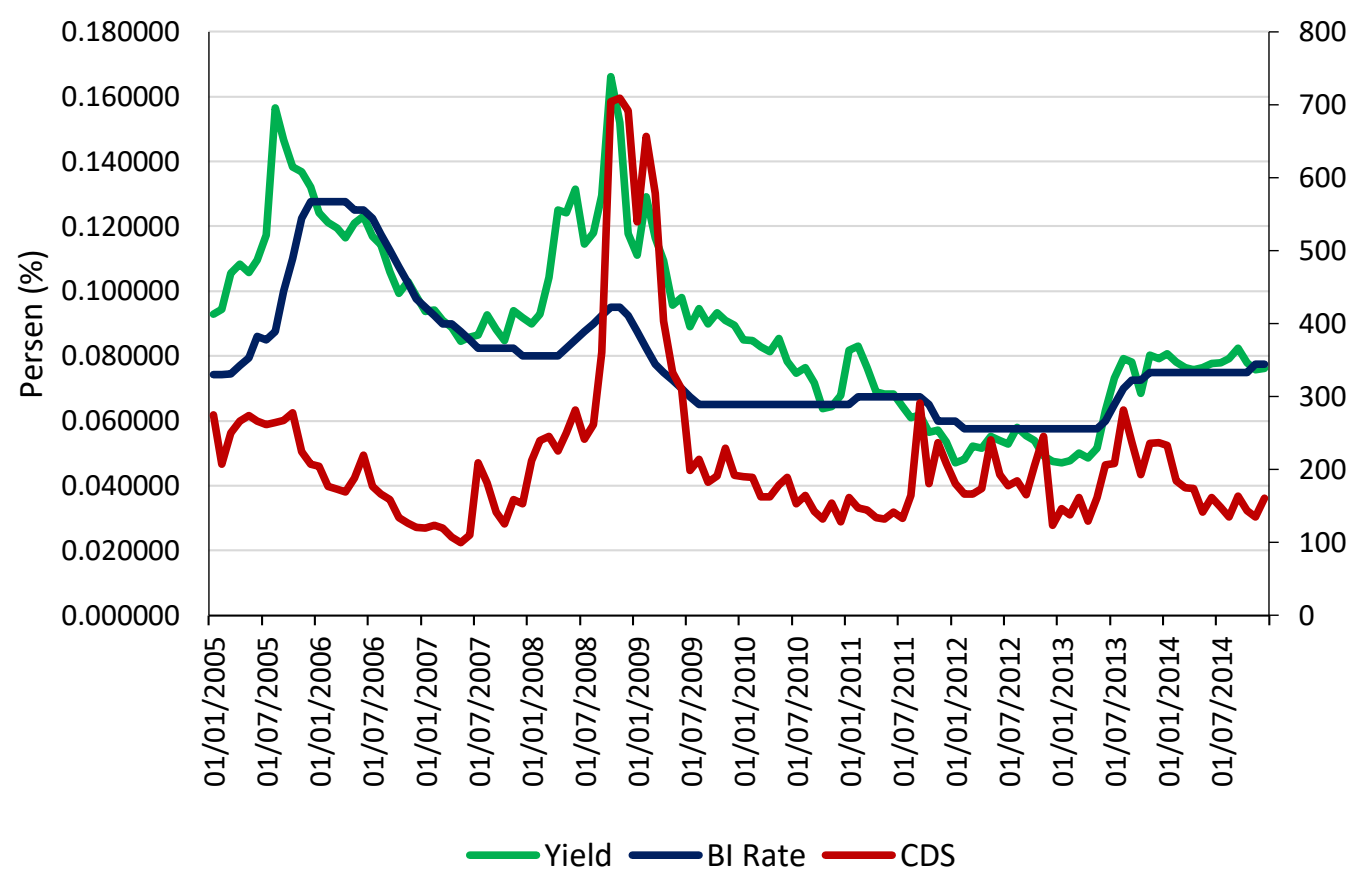

Gambar 4. Pergerakan BI Rate, Bond Yield dan Credit Default Swap (CDS) Periode 2005:01-2014:12

Sumber: Bloomberg dan Bank Indonesia (BI), 2015(diolah)

Selain itu, pergerakan nilai tukar mengalami volatile setiap bulannya. Ketika terjadi krisis global pada 31 Desember 2008 menyebabkan nilai tukar mengalami depresiasi sebesar Rp.12.360/US\$ menjadi Rp.11.120/US\$ atau naik sebesar 10\% jika dibandingkan dengan bulan sebelumnya (Gambar. 4). Kondisi ini diikuti dengan penurunan level credit default swap (CDS) dari 709 bps menjadi 691 bps atau turun sebesar $2.47 \%$, diikuti dengan penguatan IHSG sebesar $9.1 \%$, penurunan BI Rate, meskipun Pertumbuhan PDB masih mengalami perlambatan karena krisis keuangan global (Gambar.5). Berdasarkan Penelitian Hull, et al.(2004) menyatakan bahwa kenaikkan credit default swap (CDS) diikuti dengan kenaikkan yield spread. 


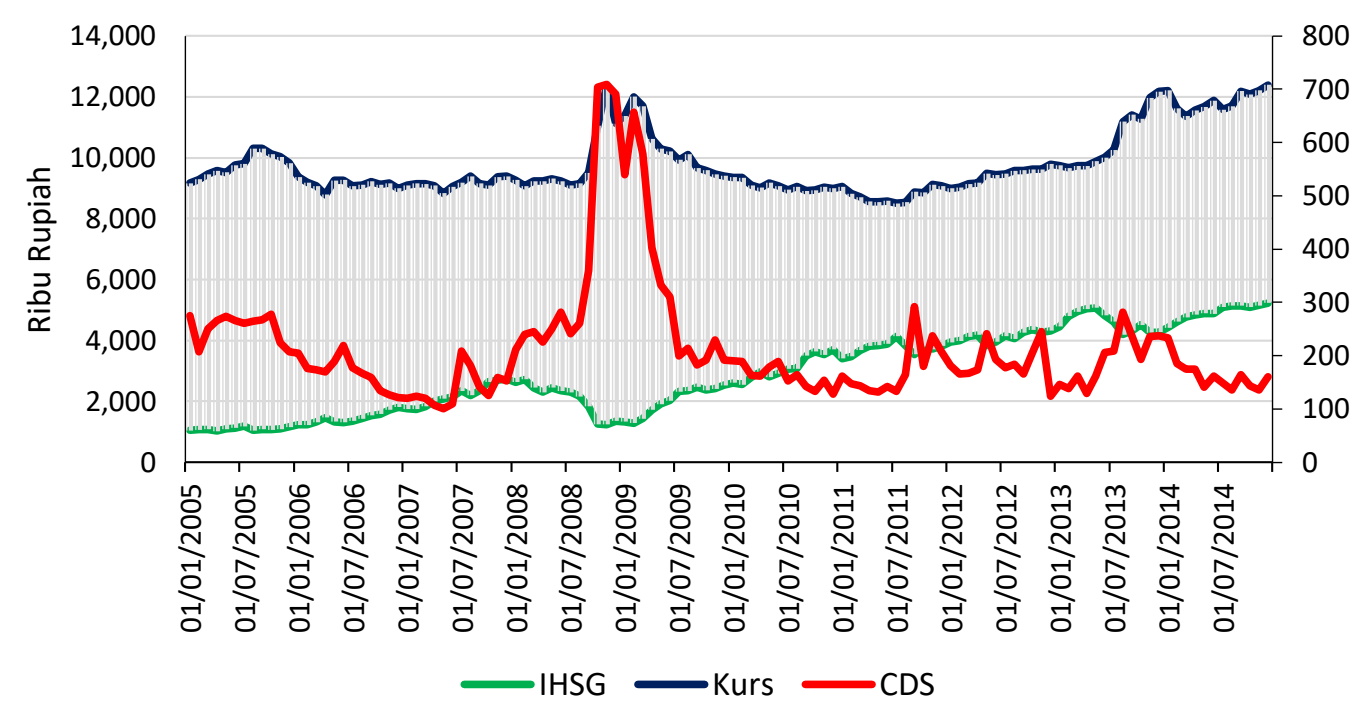

Gambar 5. Indek Harga Saham Gabungan (IHSG), Kurs dan Credit Default Swap (CDS) Periode 2005:01-2014:12

Sumber: Bloomberg dan Bank Indonesia (BI), 2015(diolah)

Berdasarkan latar belakang sebelumnya, penelitian ini bertujuan untuk melihat dampak kebijakan moneter perbankan dan makroekonomi di sektor riil terhadap credit default swap (CDS) di Indonesia sebagai negara berkembang dengan perekonomian terbuka. Selain itu, penelitian ini juga untuk mengetahui seberapa besar pengaruh sektor perbankan dan variabel riil dalam menjelaskan fluktuasi ekonomi yang menyebabkan krisis di Indonesia. Untuk mencapai tujuan tersebut menggunakan model analisis structural vector autoregresion (SVAR). Penelitian Siregar dan Ward (2000) dengan menggunakan metodologi SVAR yang ditunjukkan dari analisis IRF dan FEVD.

Penelitian ini merupakan kelanjutan dari penelitian sebelumnya Kim, et al. (2015), Ismailescu, et al. (2015), C.Calani, et al. (2013), Aini (2012), Eyssell, et al. (2010) dan Calice, et al. . (2009), yang dianalisis berkaitan dengan sovereign CDS sebagai indikator ekonomi, dampak volatilitas pasar CDS, dan credit default swap (CDS) untuk sovereign debt. Perbedaannya penelitian ini adalah bagaimana respon variabel-variabel sektor riil dan perbankan yang terdiri dari antara IHSG, BI Rate, cadangan devisa, PDB growth, kurs dan bond yield terhadap credit default swap (CDS) dengan menggunakan impulse response function (IRF) dan kontribusi variabel yang berperan penting menjelaskan perubahan credit default swap (CDS) dengan menggunakan forecast error variance decomposition (FEVD).

\section{TINJAUAN PUSTAKA}

Studi yang dilakukan Whetten, et al (2004) yang menyatakan bahwa CDS dapat dilakukan dengan menggunakan pendekatan asuransi Seorang pembeli CDS memperoleh asuransi atas minimal harga underlying securities. Apabila terjadi credit event maka pembeli CDS dapat menukarkan surat berharga yang dimilikinya dan penjual CDS dengan cash per value. Pada skema, diasumsikan pembeli CDS dapat menjual sendiri surat berharga yang dimilikinya dan penjual CDS akan mengkompensasi kekurangan per value. Sehingga penjual CDS hanya membayar $(1-\alpha)$, dimana $\alpha$ adalah nilai pasar surat berharga pasca credit event (recovery rate). Munculnya credit default swap (CDS) pada tahun 1990 yang dianggap sebagai suatu 
instrumen untuk mengalihkan resiko default oleh aset yang dikelolah oleh pihak ketiga (Numora, 2004).

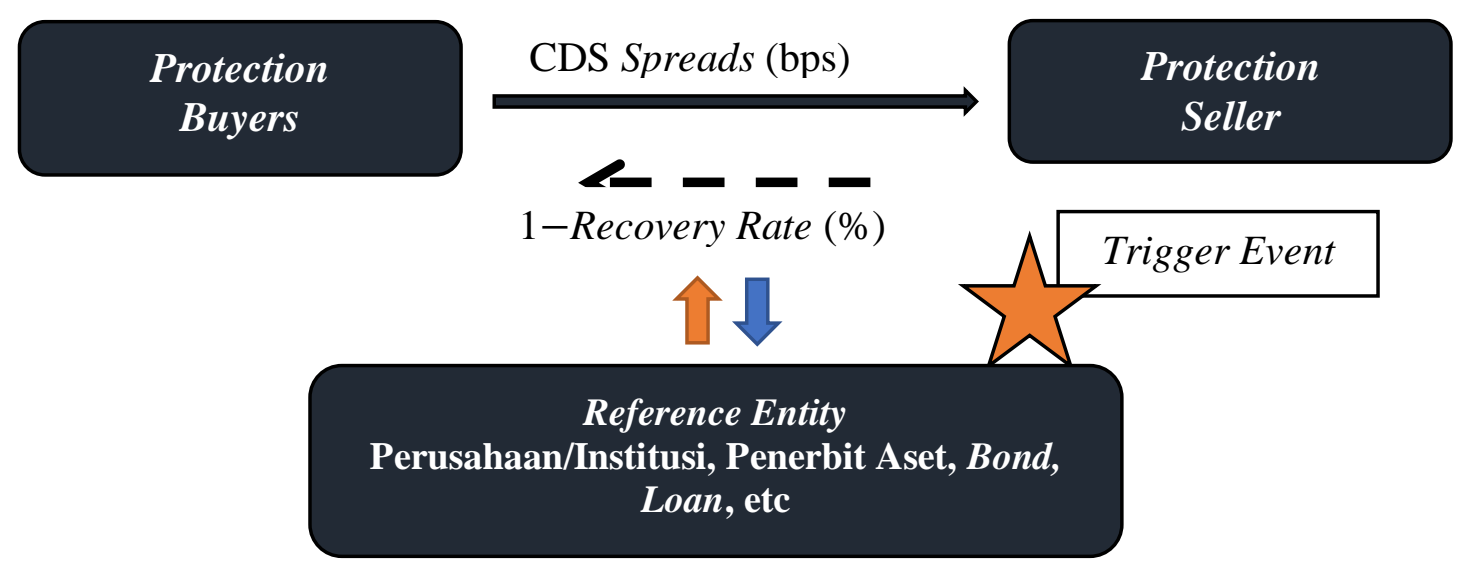

Gambar 6. Skema Credit Default Swaps (CDS)

Sumber: Whetten, et al. (2004)

Penelitian ini sejalan dengan beberapa penelitian seperti Ariefianto dan Soepomo(2011), Tampubolon dan Hidayat(2011), Jacobs,et.al.(2011), Aini (2012), Anggraini (2014), Ismailescu, et al.(2015) dan Kim, et al.(2015) menyatakan bahwa pengaruh perbankan dan sektor riil variabel seperti indeks harga saham(IHSG), suku bunga, pertumbuhan PDB, cadangan devisa, nilai tukar, yield obligasi terhadap credit default swap (CDS) di Indonesia. Sementara, adanya berita makroekonomi yang buruk secara signifikan berpengaruh terhadap peningkatan credit default swap (CDS).

\section{METODE}

Jenis data yang digunakan dalam penelitian ini adalah time series bulanan 2005:01-2014:12. Untuk pertumbuhan PDB dilakukan interpolasi mengkonversi data GDP kuartalan menjadi bulanan. Data yang digunakan dalam penelitian ini terdiri dari variabel sektor riil PDB (tahun dasar 2000) dan cadangan devisa, sementara untuk variabel perbankan sektor yang digunakan adalah indeks harga saham, BI rate, nilai tukar dan yield obligasi. Sebagian besar data yang diperoleh dari statistik keuangan dan ekonomi diterbitkan oleh Bank Indonesia, Badan Pusat Statistik dan Bloomberg.

\section{Analisis data}

Langkah-langkah analisis estimasi penelitian ini mengikuti standar SVAR. Pertama dengan melakukan uji stasioner data, untuk data yang tidak stasioner dapat menyebabkan autokorelasi dalam estimasi (Wardhana, 2005) dan data tidak dapat dijadikan acuan valid (Gujarati dan Porter, 2009). Jika data yang stasioner pada tingkat level dan,memiliki hubungan teoritis maka model estimasi SVAR dapat digunakan (Sim, 1980). Sebaliknya jika data tidak stasioner tingkat level atau first difference namun memiliki berkointegrasi, maka dapat digunakan estimasi VECM. Selanjutnya, penentuan lag optimal untuk menentukan jumlah lag optimal menurut Ajija, et al. (2011) menggunakan kriteria informasi yang dipilih seperti Prediksi Error Correction (FPE) atau kriteria dari AIC, SIC, dan HQ dengan menentukan kriteria yang terkecil di 
antara yang lain. Setelah itu, dilakukan analisis impulse response functions (IRF) dan forecast error variance decomposition (FEVD).

Prosedur untuk uji Stasioneritas yang akan digunakan dalam penelitian ini berdasarkan penelitian Zivot dan Andrews (1992), yang mendeteksi keberadaan unit roots dan structural break. Ketika melakukan uji stasioneritas dengan keberadaan structural break menunjukkan bahwa data stasioner pada tingkat level, sedangkan untuk data yang tidak menggunakan structural break menunjukkan data tidak stasioner pada tingkat level tetapi stasioner di tingkat first difference.

Penelitian Arrufat, et al. (1999) menyatakan bahwa metodologi tes ZA tidak hanya menjelaskan adanya unit roots, tetapi juga perkembangan data pada saat break point atau pertubahan stuctural break pada data sebagai fenomena eksogen. Model penelitian Zivot -Andrews tentang perubahan struktural terdiri dari tiga bagian pada tabel berikut:

Tabel 1. Model Perubahan Struktural Zivot dan Andrews (1992)

\begin{tabular}{c|c}
\hline Model & Persamaan \\
\hline Model A & $Y_{t}=\hat{\alpha}+\hat{\beta} Y_{t-1}+\hat{\delta}_{t}+\sum_{i=1}^{n} Y_{t-i}+\widehat{\Phi} D U_{t}(\hat{\lambda})+\hat{\varepsilon}_{1 \mathrm{t}}$ \\
Model B & $Y_{t}=\hat{\alpha}+\hat{\beta} Y_{t-1}+\hat{\delta}_{t}+\sum_{i=1}^{n} Y_{t-i}+\widehat{\Psi} D T_{t}(\hat{\lambda})+\hat{\varepsilon}_{2 \mathrm{t}}$ \\
Model C & $Y_{t}=\hat{\alpha}+\hat{\beta} Y_{t-1}+\hat{\delta}_{t}+\sum_{i=1}^{n} Y_{t-i}+\widehat{\Phi} D U_{t}(\hat{\lambda})+\hat{\Psi} D T_{t}(\hat{\lambda})+\hat{\varepsilon}_{3 \mathrm{t}}$ \\
\hline
\end{tabular}

Dimana, $\varepsilon$ dan $t$ adalah konstanta dan trend. Dalam persamaan (1), (2) dan (3) yang masing-masing merupakan model A (break tanpa konstanta), B (break pada trend), dan $\mathrm{C}$ (break pada konstanta dan trend). Perubahan struktural dalam penelitian Andrews dan Zivot (1992) mengembangkan tiga model untuk uji stasioner yaitu:

Pada Model A menggambarkan perubahan struktural pada intersep atau yang lebih dikenal dengan shift in mean model. Oleh karena itu, $D U_{t}(\lambda)$ merupakan dummy mean atau dummy yang menangkap perubahan struktural pada intersep $(\alpha)$. Jika terjadi perubahan struktural, diharapkan nilai $\widehat{\Phi}$ signifikan secara statistik sehingga akan menambah nilai $\hat{\alpha}$, dengan syarat nilai $\widehat{\Phi}$ harus signifikan secara statistik.

Model B, menggambarkan_perubahan struktural pada intersep atau yang lebih dikenal dengan shift in trend model. Di mana untuk $D T_{t}(\boldsymbol{\lambda})$ adalah dummy trend yang mengakap perubahan struktur pada trend $(\mathrm{t})$. Jika terjadi perubahan struktural, diharapkan nilai $\widehat{\Psi}$ signifikan secara statistik sehingga akan menambah nilai $\hat{\delta}$, dengan syarat nilai $\widehat{\Phi}$ harus signifikan secara statistik.

Model C, yang menggambarkan perubahan struktural pada intersep atau yang lebih dikenal dengan shift in mean dan trend model. Di mana, untuk $\operatorname{DUt}(\hat{\lambda}) \operatorname{dan} \operatorname{DTt}(\hat{\lambda})$ yang dikenal sebagai variable dummy regime yang berfungsi menangkap perubahan struktural pada intersep $\hat{\alpha}$ dan trend $(\mathrm{t})$. Berdasarkan model ZA di atas, penentuan ada tidaknya perubahan struktural di identifikasi berdasarkan $\widehat{\Psi}$ dan nilai $\widehat{\Phi}$ signifikan secara statistik sehingga akan menambah nilai $\hat{\delta}$ dan nilai $\hat{\alpha}$.

Dimana, untuk variabel $\operatorname{DUt}(\hat{\lambda})=1$, jika $\mathrm{t}>\mathrm{T} \lambda$ dan 0 sebaliknya, $\operatorname{DTt}(\hat{\lambda})=\mathrm{t}-\mathrm{T} \lambda$ dan 0 sebaliknya. T adalah jumlah observasi dan $\lambda$ adalah break fraction, dengan rentang $[2 / T,(T-1) / T]$, Secara umum, T $\lambda$ merupakan suatu periode tertentu di dalam observasi. Untuk uji structural break ZA, apabila hipotesis awal atau $H_{0}$ jika, $\delta=0$ diterima maka penelitian tersebut dapat dikatakan terdapat structural break. Hal ini juga dapat dilihat dari nilai t-stat yang lebih besar nilai kritis ZA yang mengambarkan bahwa pada penelitian ini terdapat structural break dan data stasioner, sebaliknya apabila 
hipotesis alternatif atau $H_{a}$ diterima dimana nilai $\delta<0$, hal ini menggambarkan bahwa pada penelitian ini terdapat structural break tetapi data tidak stasioner.

Dalam perkembangan beberapa ekonom mengembangkan model VAR berdasarkan hubungan variabel yang dikenal sebagai SVAR. Model SVAR adalah model VAR dari teoritis dan teristriksi. Estimasi prosedur dalam penelitian ini mulai dari penelitian variabel identifikasi, stasioneritas tes, penentuan panjang lag, model uji stabilitas, pembentukan SVAR. Kemudian, analisis IRF dan FEVD untuk mengetahui fluktuasi sumber dalam variabel tertentu. Dalam estimasi dan analisis ekonometrik penulis menggunakan bantuan eviews 8. persamaan umum menggunakan matriks notasi ditampilkan dalam persamaan berikut:

$X_{t}=A_{0} D_{t}+A_{1} X_{t-1}+A_{2} X_{t-2}+\ldots+A_{p} X_{t-p}+B_{0} X_{t}+\varepsilon_{\mathrm{t}}$

$X_{t}=A_{0}+A_{1} X_{t-1}+A_{2} X_{t-2}+\ldots+A_{p} X_{t-p}+\varepsilon_{\mathrm{t}}$

Dimana:

$X_{t}=$ vektor containing $n$ variables in the system SVAR $(\mathrm{n} \times 1)$

$A_{0}=$ vektor intersept $(\mathrm{n} \times 1)$

$A_{t}=$ matrik koefisien $(\mathrm{n} \times \mathrm{n})$

$\varepsilon_{t}=$ vektor variabel gangguan ( $\mathrm{n} \times 1$ ), atau proses white nose (independent terhadap prilaku historis credit default swap(CDS), IHSG, BI Rate, cadangan devisa, PDB growth, kurs, dan yield.

Restriksi dalam model SVAR yang digunakan dalam penelitian ini dibentuk berdasarkan asumsi yang terdapat dalam model Parrado (2001). Dengan demikian maka model kerangka SVAR dalam penbelitian ini dapat dinyatakan pada persamaan matriks sebagai berikut:

$$
\left[\begin{array}{l}
\varepsilon_{1 t} \\
\varepsilon_{2 t} \\
\varepsilon_{3 t} \\
\varepsilon_{4 t} \\
\varepsilon_{5 t} \\
\varepsilon_{6 t} \\
\varepsilon_{7 t}
\end{array}\right]=\left[\begin{array}{ccccccc}
1 & 0 & 0 & 0 & 0 & 0 & 0 \\
C_{21} & 1 & 0 & 0 & 0 & 0 & 0 \\
C_{31} & C_{32} & 1 & 0 & 0 & 0 & 0 \\
C_{41} & 0 & 0 & 1 & 0 & 0 & 0 \\
C_{51} & 0 & 0 & C_{54} & 1 & 0 & 0 \\
0 & C_{62} & C_{63} & C_{64} & C_{65} & 1 & 0 \\
C_{71} & C_{72} & C_{73} & C_{74} & C_{75} & C_{76} & 1
\end{array}\right]\left[\begin{array}{l}
\mu_{1 t} \\
\mu_{2 t} \\
\mu_{3 t} \\
\mu_{4 t} \\
\mu_{5 t} \\
\mu_{6 t} \\
\mu_{7 t}
\end{array}\right]
$$

Di mana, $\varepsilon_{1 t}, \varepsilon_{2 t}, \varepsilon_{3 t}, \varepsilon_{4 t}, \varepsilon_{5 t}, \varepsilon_{6 t}$ dan $\varepsilon_{7 t}$ masing-masing adalah structural disturbance gangguan variabel sektor riil dan perbankan, dan credit default swap (CDS). Sedangkan $\mu_{1 t}, \mu_{2 t}, \mu_{3 t}, \mu_{4 t}, \mu_{5 t}, \mu_{6 t}$, dan $\mu_{7 t}$ adalah residual shock dari masing-masing variabel tersebut.

Selanjutnya, analisis IRF dapat melihat lamanya pengaruh dari shock suatu variabel terhadap variabel lain sampai pengaruhnya hilang atau kembali ke titik keseimbangan dapat dilihat atau diketahui (Ajija, et al. 2011). Kemudian menurut Pindyck (1991) menyatakan bahwa IRF merupakan salah satu metode estimasi VAR yang digunakan untuk melihat respon variabel endogen terhadap adanya keterkaitan inovasi (shock) dari variabel endogen lainnya. Persamaan model umum dengan Hill, et al (2011) dengan persamaan (5) Dan (6) sebagai berikut:

$$
\begin{aligned}
& y_{t}=\delta_{10}+\delta_{11} y_{t-1}+\delta_{12} x_{t-1}+v_{t}^{y} \\
& x_{t}=\delta_{20}+\delta_{21} y_{t-1}+\delta_{22} x_{t-1}+v_{t}^{x}
\end{aligned}
$$


Dengan demikian, dapat disimpulkan bahwa metode IRF dapat digunakan untuk melihat efek shock atau standar deviasi suatu variabel pada periode sebelumnya terhadap nilai sekarang (current time value) dengan nilai yang akan datang dari beberapa variabel endogen yang di dalam suatu model (Hadi, 2013).

Sementara itu, variance decomposition menjelaskan proporsi dari pergerakan secara sequential setiap variabel terhadap shock-nya sendiri terhadap shock variabel yang lain pada periode yang akan datang, sehingga dapat digunakan sebagai prediksi kontribusi persentase varians setiap variabel terhadap perubahan suatu variabel tertentu. Persamaan umum variance decomposition dijelaskan pada persamaan berikut:

$$
\begin{aligned}
& v_{t+1}^{F}=E_{t}\left[\delta_{11} y_{t}+\delta_{12} x_{t}+v_{t+1}^{y}\right]=\delta_{11} y_{t}+\delta_{12} x_{t} \\
& v_{t+1}^{F}=E_{t}\left[\delta_{21} y_{t}+\delta_{22} x_{t}+v_{t+1}^{x}\right]=\delta_{21} y_{t}+\delta_{22} x_{t}
\end{aligned}
$$

Adanya kesalahan perkiraan periode ke-2 dari forecast error dan variance pada independen error di jelaskan pada persamaan berikut:

$$
\begin{gathered}
F E_{2}^{y}=y_{t+2}-E_{t}\left[y_{t+2}\right]=\left[\delta_{11} v_{t+1}^{y}+\delta_{12} v_{t+1}^{x}+v_{t+2}^{y}\right] \\
\operatorname{var}\left(F E_{2}^{y}\right)=\delta_{11}^{2} \sigma_{y}^{2}+\delta_{12}^{2} \sigma_{x}^{2}+\sigma_{y}^{2} \\
F E_{2}^{x}=x_{t+2}-E_{t}\left[x_{t+2}\right]=\left[\delta_{21} v_{t+1}^{y}+\delta_{22} v_{t+1}^{x}+v_{t+2}^{x}\right] \\
\operatorname{var}\left(F E_{2}^{x}\right)=\delta_{21}^{2} \sigma_{y}^{2}+\delta_{22}^{2} \sigma_{x}^{2}+\sigma_{x}^{2}
\end{gathered}
$$

\section{HASIL DAN PEMBAHASAN}

\section{Uji stasioneritas}

Dalam penelitian ini melakukan uji stasioneritas data Zivot dan Andrews terhadap variabel-variabel credit default swap (CDS), sektor riil dan perbankan di Indonesia periode 2005:01-2014:12. Berdasarkan estimasi yang dilakukan diperoleh hasil bahwa semua data stasioner pada tingkat level dan sebagian besar data yang besar terdapat structural break (Tabel 3). Kemudian, dengan melakukan uji Zivot dan Andrews

\begin{tabular}{|c|c|c|c|c|c|}
\hline \multirow{2}{*}{ Variabel } & \multirow{2}{*}{$\begin{array}{c}\text { Critical } \\
\text { Value } \\
(1 \%)\end{array}$} & \multicolumn{3}{|c|}{ Level } & \multirow{2}{*}{ Ket } \\
\hline & & t-statistik & DU & DT & \\
\hline CDS* & \pm 5.57 & $18.41292(2)$ & 0.519451 & 0.414896 & $\begin{array}{l}\text { Stationer, karena t stat } \\
\left.\mathrm{CDS}_{\mathrm{t}-1}>5.57 \text { (critcal value }\right)\end{array}$ \\
\hline IHSG* & \pm 5.57 & $29.5355(33)$ & 3.454514 & 0.927514 & $\begin{array}{l}\text { Stationer, karena t stat } \\
\text { IHSG }_{\mathrm{t}-1}>5.57(\text { critcal value })\end{array}$ \\
\hline BI Rate* & \pm 5.57 & $52.0725(19)$ & 2.05825 & -5.13891 & $\begin{array}{l}\text { Stationer, karena t stat } \\
\left.\text { BI Rate }_{\mathrm{t}-1}>5.57 \text { (critcal value }\right)\end{array}$ \\
\hline Cad_Dev* & \pm 5.57 & $18.39088(3)$ & 0.759704 & 0.160681 & $\begin{array}{l}\text { Stationer, karena t stat } \\
\left.\text { Cad_Dev }_{\mathrm{t}-1}>5.57 \text { (critcal value }\right)\end{array}$ \\
\hline PDB_Growth & \pm 5.57 & $7.080679(30)$ & -0.924662 & $\begin{array}{c}- \\
1.005312\end{array}$ & $\begin{array}{l}\text { Stationer, karena t stat } \\
\text { PDB_Growth }{ }_{\mathrm{t}-1}>5.57 \text { (critcal value) }\end{array}$ \\
\hline Kurs* & \pm 5.57 & $31.3071(30)$ & -3.7816 & 0.211306 & $\begin{array}{l}\text { Stationer, karena t stat } \\
\left.\text { Kurs }_{\mathrm{t}-1}>5.57 \text { (critcal value }\right)\end{array}$ \\
\hline Yield* & \pm 5.57 & $21.6398(30)$ & 1.279485 & 1.870510 & $\begin{array}{l}\text { Stationer, karena t stat } \\
\left.\text { Yield }_{t-1}>5.57 \text { (critcal value }\right)\end{array}$ \\
\hline
\end{tabular}
terlihat adanya Breakpoint dalam perkembangan perekonomian yang terjadi selama periode pengamatan (Tabel4). Uji ZA yang dilakukan dengan menggunakan trimming region mulai dari regresi ke -1 pada data ke-19 dan diakhiri pada regresi ke-85 pada data ke-103.

Tabel 2. Uji Stasioneritas Zivot dan Andrews Test Model Shift in Regime

Sumber: Bloomberg, Bank Indonesia dan Badan Pusat Statistik (BPS), 2015(diolah) 
Keterangan: Stasioner pada tingkat critical value $1 \%$ yaitu \pm 5.57 yang ditunjukkan $\mathrm{t}$ statistik dan () adalah regresi ke $\mathrm{n}$ dan simbol * menunjukkan variabel terdapat structural break pada probabilitas $1 \%, 5 \%$, dan $10 \%$.

Berdasarkan uji Zivot dan Andrews pada tabel 3 menunjukkan bahwa data signifikan pada tingkat $1 \%$ sehingga dapat dikatakan bahwa variabel penelitian stasioner pada tingkat level. Pada uji Zivot dan Andrews (ZA), variabel-variabel penelitian seperti credit default swap (CDS), indeks harga saham gabungan (IHSG), BI Rate, cadangan devisa, pertumbuhan PDB, kurs dan bond yield ditunjukkan | nilai statistik ZA $|>|$ critical value $1 \% \mid$, dimana critical value $1 \%$ yang digunakan adalah sebesar \pm 5.57 .

Tabel 3. Uji Structural Break Zivot dan Andrews

\begin{tabular}{|c|c|c|}
\hline Variabel & $\begin{array}{c}\text { Jumlah } \\
\text { Structural } \\
\text { Break }\end{array}$ & Tahun Structural Break \\
\hline CDS* & 20 & $\begin{array}{l}\text { Februari 2007, Maret 2007, April 2007, Mei 2007, Juli 2007, Juni } \\
\text { 2007, Oktober 2007, November 2007, Desember 2007, November } \\
\text { 2008, Desember 2008, Januari 2009, Februari 2009, Maret 2009, } \\
\text { April 2009, Mei 2009, Juni 2009, Juli 2009, Desember 2009, Februari } \\
\text { 2012. }\end{array}$ \\
\hline IHSG* & 20 & $\begin{array}{l}\text { Agustus 2007, Oktober 2007, November 2007, Desember 2007, } \\
\text { Januari 2008, Februari 2008, Maret 2008, April 2008, Mei 2008, Juni } \\
\text { 2008, Juli 2008, November 2008, Desember 2008, Januari 2009, } \\
\text { Februari 2009, Maret 2009, April 2009, Mei 2009, Juni 2009, dan Juli } \\
2009 \text {. }\end{array}$ \\
\hline BI Rate* & 85 & Juli 2006 sampai Juli 2013 terjadi struktural break \\
\hline Cad_Dev* & 60 & $\begin{array}{l}\text { Desember 2007, Januari 2008, Maret 2008, April 2008, Mei 2008, } \\
\text { Juni 2008, Juli 2008, Agustus 2008, September 2008, Oktober 2008, } \\
\text { November 2008, Desember 2008, Januari 2009, Februari 2009, Maret } \\
\text { 2009, April 2009, Mei 2009, Juni 2009, Juli 2009, Agustus 2009, } \\
\text { September 2009, Oktober 2009, November 2009, Desember 2009, } \\
\text { Januari 2010, Februari 2010, Maret 2010, April 2010, Mei 2010, Juni } \\
\text { 2010, Juli 2010, Agustus 2010, September 2010, Oktober 2010, } \\
\text { November 2010, Desember 2010, Januari 2011, Februari 2011, Maret } \\
\text { 2011, April 2011, Mei 2011, Juni 2011, Juli 2011, Agustus 2011, } \\
\text { September 2011, Oktober 2011, November 2011, Desember 2011, } \\
\text { Januari 2012, Februari 2012, Maret 2012, April 2012, Mei 2012, Juni } \\
\text { 2012, Juli 2012, Agustus 2012, September 2012, Oktober 2012, } \\
\text { November 2012, Desember 2012. }\end{array}$ \\
\hline PDB_Growth & 0 & Tidak ada Structural Break \\
\hline Kurs* & 50 & $\begin{array}{l}\text { November 2008, Desember 2008, Januari 2009, Februari 2009, } \\
\text { Maret 2009, April 2009, Mei 2009, Juni 2009, Juli 2009, Agustus } \\
\text { 2009, September 2009, Oktober 2009, November 2009, Desember } \\
\text { 2009, Januari 2010, Februari 2010, Maret 2010, April 2010, Mei } \\
\text { 2010, Juni 2010, Juli 2010, Agustus 2010, September 2010, Oktober } \\
\text { 2010, November 2010, Desember 2010, Januari 2011, Februari 2011, } \\
\text { Maret 2011, April 2011, Mei 2011, Juni 2011, Juli 2011, Agustus } \\
\text { 2011, September 2011, Oktober 2011, November 2011, Desember } \\
\text { 2011, Januari 2012, Februari 2012, Maret 2012, April 2012, Mei } \\
\text { 2012, Juni 2012, Juli 2012, Maret 2013, April 2013, Mei 2013, Juni } \\
\text { 2013, Juli 2013. }\end{array}$ \\
\hline Yield & 54 & $\begin{array}{l}\text { Februari 2007, Maret 2007, April 2007, Mei 2007, Juni 2007, Juli } \\
\text { 2007, Agustus 2007, September 2007, Oktober 2007, November } \\
\text { 2007, November 2008, Desember 2008, Januari 2009, Maret 2009, } \\
\text { April 2009, Mei 2009, Januari 2010, Februari 2010, Maret 2010, } \\
\text { April 2010, Mei 2010, Juni 2010, Juli 2010, Agustus 2010, } \\
\text { September 2010, Oktober 2010, November 2010, Desember 2010, } \\
\text { Januari 2011, Februari 2011, Maret 2011, April 2011, Mei 2011, Juni } \\
\text { 2011, Juli 2011, Agustus 2011, September 2011, Oktober 2011, }\end{array}$ \\
\hline
\end{tabular}


November 2011, Desember 2011, Januari 2012, Februari 2012, Maret 2012, April 2012, Mei 2012, Juni 2012, Juli 2012, Agustus 2012, September 2012, Maret 2013, April 2013, Mei 2013, Juni 2013, Juli 2013.

\section{Sumber: Bloomberg, Bank Indonesia, dan Badan Pusat Statistik (BPS),(2015)}

Structural break merupakan salah satu konsep ekonometrik yang menggambarkan perubahan dan pergeseran yang tidak terduga Adanya structural break menyebabkan kesalahan peramalan dari model sehingga target akan sulit dicapai. Berdasarkan hasil analisis dapat disimpulkan bahwa sebagian besar variabel-variabel penelitian terdapat structural break seperti credit default swap (CDS), IHSG, BI Rate, cadangan devisa, kurs dan yield yang masing-masing adalah 20 kali structural break, 20 kali structural break, 85 kali structural break, 60 kali structural break, 50 kali structural break, 54 kali structural break. Sedangkan variabel pertumbuhan PDB tetapi tidak terdapat structural break.

\section{Penentuan lag optimal}

Setelah dilakukan uji stasioneritas menggunakan uji Zivot dan Andrews, maka tahap selanjutnya adalah penentuan lag optimum (Tabel 5). Berdasarkan hasil estimasi menunjukkan bahwa lag optimal dalam penelitian ini ditunjukkan pada lag 5 sebagai lag optimum dalam sistem SVAR. Hal ini berdasarkan dengan nilai squential modified LR test statistic (LR), final prediction error correction (EPE), dan Akaike Information Criterion (AIC) yang terkecil.

Tabel 4. Uji Lag Optimum

\begin{tabular}{r|cccccc}
\hline Lag & LogL & LR & FPE & AIC & SC & HQ \\
\hline 0 & 1034.966 & NA & $4.06 \mathrm{e}-17$ & -17.87766 & -17.71058 & -17.80984 \\
1 & 1903.738 & 1616.673 & $2.62 \mathrm{e}-23$ & -32.13458 & $-30.79792^{*}$ & -31.59204 \\
2 & 1998.987 & 165.6501 & $1.18 \mathrm{e}-23$ & -32.93891 & -30.43267 & $-31.92164^{*}$ \\
3 & 2062.572 & 102.8422 & $9.37 \mathrm{e}-24$ & -33.19257 & -29.51674 & -31.70057 \\
4 & 2125.737 & 94.47170 & $7.66 \mathrm{e}-24$ & -33.43890 & -28.59350 & -31.47217 \\
5 & 2192.961 & $92.36005^{*}$ & $6.01 \mathrm{e}-24 *$ & $-33.75584^{*}$ & -27.74086 & -31.31439 \\
\hline
\end{tabular}

Sumber: Bloomberg, Bank Indonesia, dan Badan Pusat Statistik (BPS),(2015)

Keterangan: Tanda (*) menggambarkan order lag yang dipilih berdasarkan kriteria pada masing-masing lag.

\section{Stabilitas model}

Model stabilitas SVAR dilakukan dengan melihat nilai roots dan karakteristik polinominal AR dilihat pada nilai modulus di tabel AR rootsnya. erdasarkan hasil estimasi yang telah dilakukan, maka uji stabilitas semua akar dalam model SVAR telah stabil. Berdasarkan hasil di (Figure.5) Tampilkan yang menunjukkan bahwa semua akar dalam model SVAR memiliki modulus yang lebih kecil dari satu dan terletak di unit lingkaran. Sehingga dapat disimpulkan Model SVAR lag 5 memiliki stabil.

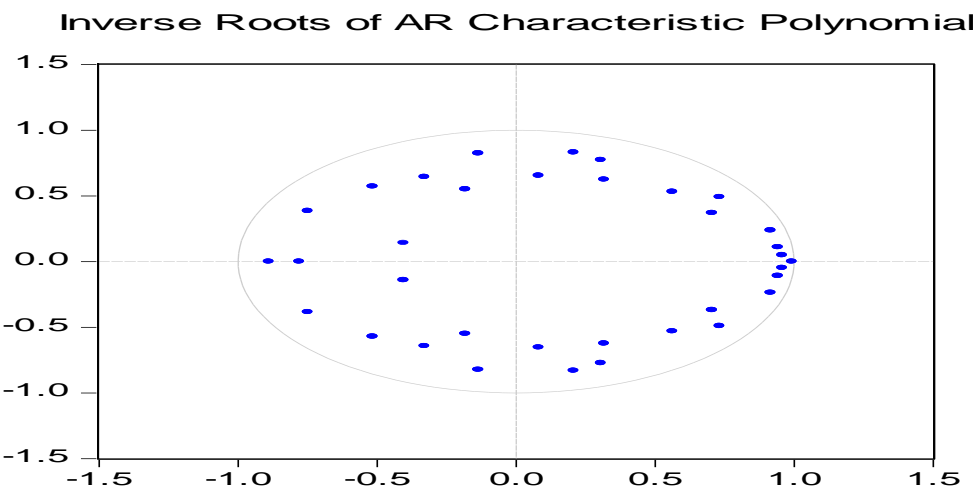


Sumber: Bloomberg, Bank Indonesia, dan Badan Pusat Statistik (BPS),(2015)

Gambar 7. Uji Stabilitas Model

Keterangan: No root lies outside the unit circle, dan VAR satisfies the stability condition.

\section{Structural vector autoregression (SVAR)}

Restriksi pada sistem SVAR menggunakan Matrix A dan B Matrix, sehingga diperoleh hasil estimasi SVAR di (Tabel 6). Berdasarkan hasil estimasi Tabel 6. menunjukkan hasil estimasi pengaruh sektor riil dan perbankan untuk credit default swap (CDS). Berdasarkan hasil etimasi itu, di mana pengaruhnya masing-masing variabel koefisien yang yang berada di materik. Meskipun koefisien telah dikenal, tapi intepretasi koefisien sulit. Oleh karena itu dilakukan fungsi analisis respon impuls (IRF) dan kesalahan perkiraan varians dekomposisi (FEVD) untuk membeli kesimpulan dari penelitian.

Tabel 5 Estimasi Structural Vector Autoregression (SVAR)

\begin{tabular}{rrrrrrr}
\hline \multicolumn{7}{c}{ Matriks koefisien A } \\
\hline 1.000000 & 0.000000 & 0.000000 & 0.000000 & 0.000000 & 0.000000 & 0.000000 \\
0.177916 & 1.000000 & 0.000000 & 0.000000 & 0.000000 & 0.000000 & 0.000000 \\
0.003687 & 0.026230 & 1.000000 & 0.000000 & 0.000000 & 0.000000 & 0.000000 \\
0.082413 & 0.360256 & 1.466303 & 1.000000 & 0.000000 & 0.000000 & 0.000000 \\
-0.859998 & -6.343810 & -19.69533 & -1.509466 & 1.000000 & 0.000000 & 0.000000 \\
-0.022668 & 0.279083 & 0.327002 & -0.053534 & -0.000207 & 1.000000 & 0.000000 \\
0.007475 & 0.218071 & 0.234798 & 0.017919 & -0.001702 & -0.074631 & 1.000000 \\
\hline \multicolumn{7}{c}{ Matriks koefisien B: } \\
\hline 0.077893 & 0.000000 & 0.000000 & 0.000000 & 0.000000 & 0.000000 & 0.000000 \\
0.000000 & 0.020577 & 0.000000 & 0.000000 & 0.000000 & 0.000000 & 0.000000 \\
0.000000 & 0.000000 & 0.001481 & 0.000000 & 0.000000 & 0.000000 & 0.000000 \\
0.000000 & 0.000000 & 0.000000 & 0.025135 & 0.000000 & 0.000000 & 0.000000 \\
0.000000 & 0.000000 & 0.000000 & 0.000000 & 0.486943 & 0.000000 & 0.000000 \\
0.000000 & 0.000000 & 0.000000 & 0.000000 & 0.000000 & 0.007412 & 0.000000 \\
0.000000 & 0.000000 & 0.000000 & 0.000000 & 0.000000 & 0.000000 & 0.004389 \\
\hline
\end{tabular}

Sumber: Bloomberg, Bank Indonesia (BI) dan Badan Pusat Statistik (BPS), (2015)

\section{Impulse Response Function (IRF)}

Untuk mengetahui perilaku suatu variabel dalam merespon suatu kejutan (Shock), dalam model SVAR biasanya digunakan impulse response function (IRF). Dalam penelitian ini, analisis IRF digunakan untuk melihat respon variabel sektor riil dan perbankan. terhadap shock credit default swap di Indonesia (Gambar 7).

Hasil analisis digambarkan dalam bentuk grafik yang terdiri dari sumbu horizontal dan sumbu vertikal. Pada sumbu horizontal menggambarkan waktu dalam periode hari ke depan setelah adanya shock, sedangkan sumbu vertikal nilai respon suatu variabel. Berdasarkan hasil penelitian dapat disimpulkan bahwa, variabel perbankan. terhadap shock credit default swap di Indonesia. memiliki kejutan yang relatif lama sebelum mencapai keseimbangan, sedangkan variabel sektor riil relatif pendek. Selain itu guncangan paling cepat direspon oleh sektor perbankan terlebih dahulu, setelah itu direspon oleh sektor riil

Pengaruh sektor riil dalam penelitian ini konsisten dengan penelitian Beers dan Cavanaugh, (2006) yang menyatakan bahwa variabel fundamental ekonomi seperti pertumbuhan PDB akan mempengaruhi perubahan premi CDS. Selanjutnya, beberapa penelitian Krugmen (1979) dan Flood dan Garber (1984) yang menyatakan adanya teori krisis generasi pertama yang menyatakan bahwa rendahnya cadangan devisa akan 
mempengaruhi depresiasi nilai tukar, selanjutnya penelitian ini sejalan dengan penelitian Ariefianto dan Soepomo (2011), Tampubolon, Hidayat (2011), Jacob, et al.(2011), dan Ismailescu, et al.(2015). 
Response of IHSG to CDS
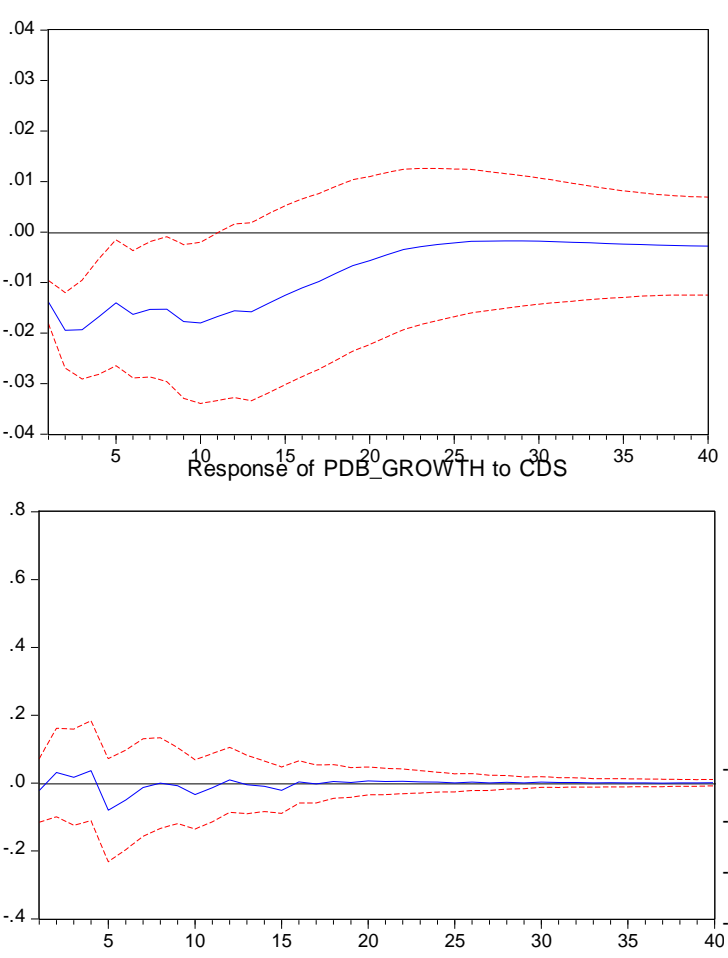

Response of BI_RATE to CDS
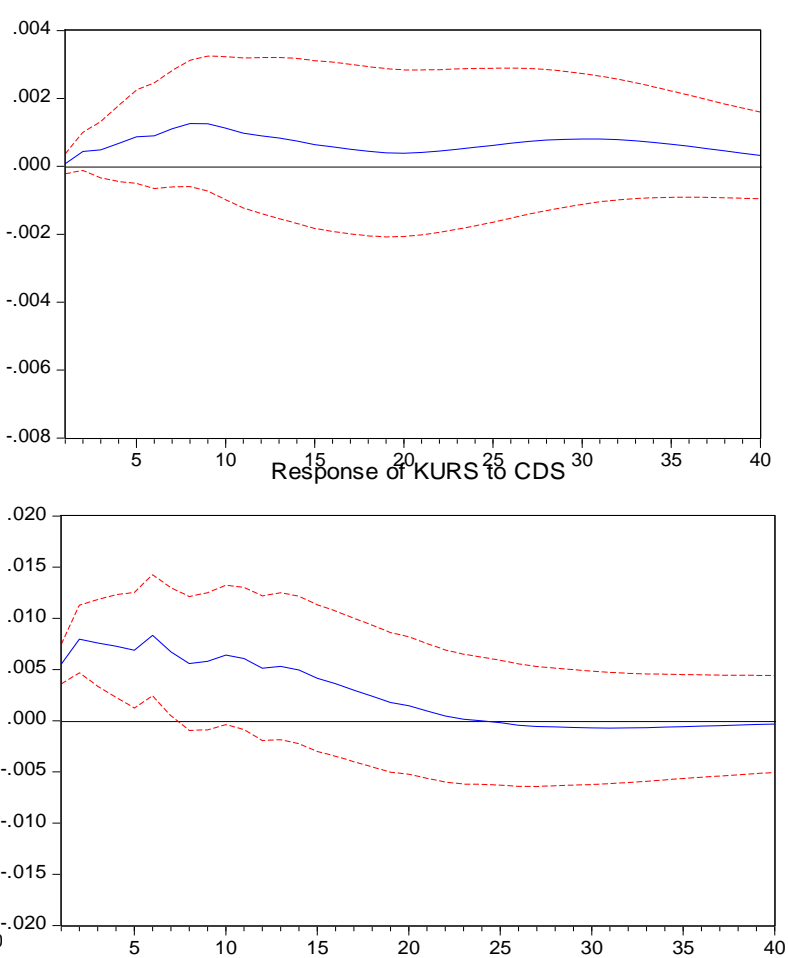

Response of CAD_DEV to CDS
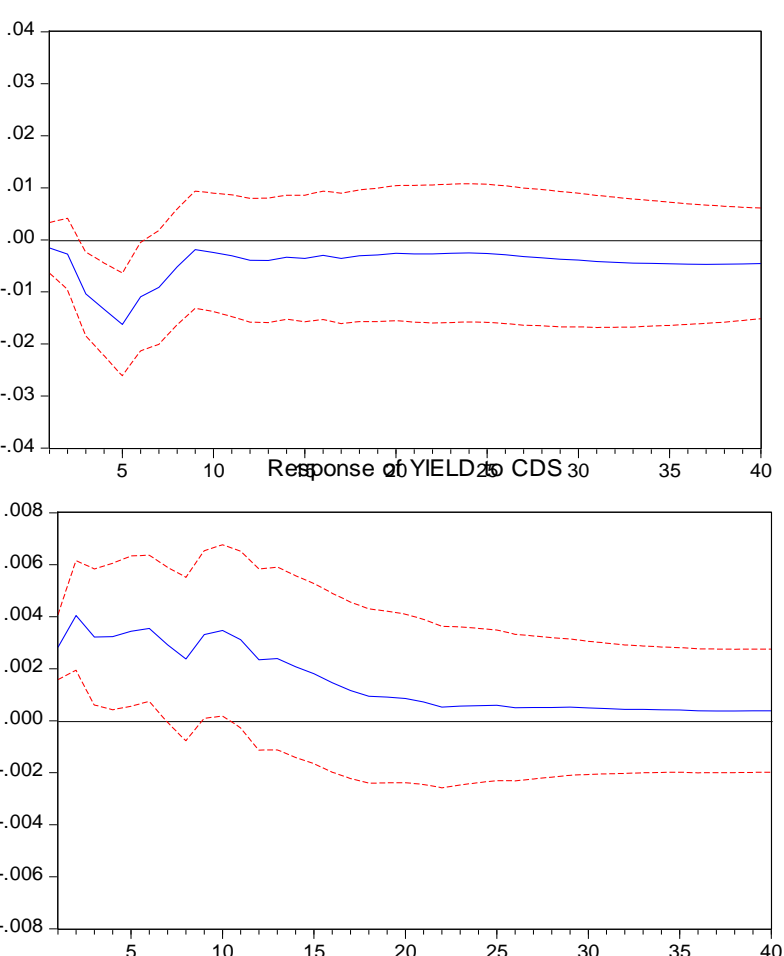

Sumber: Hasil kalkulasi dari Bloomberg, Bank Indonesia(BI) dan Badan Pusat Statistik(BPS), (2015)

Gambar 8. Respon Variabel-Variabel Sektor Riil Dan Perbankan Satu Standar Deviasi Inovasi \pm SE terhadap Nilai Credit Default Swap a) Respon nilai IHSG terhadap kenaikkan satu standar deviasi dari kejutan persentase nilai credit default swap (CDS)

b) Respon nilai BI Rate terhadap kenaikkan satu standar deviasi dari kejutan persentase credit default swap (CDS)

c) Respon nilai Cadangan Devisa terhadap kenaikkan satu standar Deviasi dari kejutan persentase credit default swap (CDS)

e) Respon nilai Kurs terhadap kenaikkan satu standar deviasi dari kejutan persentase credit default swap (CDS)

f) Respon nilai Yield terhadap kenaikkan satu standar deviasi dari kejutan persentase credit default swap (CDS)

Sementara, pengaruh sektor perbankan ini sesuai dengan beberapa penelitian Hull, et al. (2015), Alexander Kaeck (2008), Jacob, et al.(2011) dan Aini (2012) yang menyatakan bahwa pengaruh IHSG dan kurs terhadap credit default swap (CDS) mempunyai kejutan (shock) yang negatif artinya ketika ada kenaikan kejutan (shock) pada IHSG dan kurs akan merespon penurunan credit default swap (CDS). Sedangkan pada variabel-variabel seperti BI Rate, kurs dan yield terhadap credit default swap (CDS) mempunyai hubungan yang positif artinya ketika terjadi kejutan (shock) kenaikan pada variabel BI Rate, kurs dan yield akan merespon kenaikan nilai terhadap credit default swap (CDS) 


\section{Forecast Error Variance Decomposition (FEVD)}

Berdasarkan hasil analisis data yang dilakukan pada (Tabel 7), (Tabel 8), (Tabel 9), (Tabel 10), (Tabel 11), (Tabel 12), dan (Tabel 13) merupakan forecast error variance decomposition (FEVD) sektor riil dan perbankan terhadap credit default swap (CDS). Selain itu pula, FEVD digunakan untuk mengukur persentase kejutan dari masing-masing variabel penelitian dan menaggulangi kekurangan impulse response function (IRF). Beberapa pengaruh adanya kejutan variabel aliran modal pada variabel-variabel sektor riil dan perbankan terhadap credit default swap (CDS) yang diteliti adalah sebagai berikut:

Tabel 6. Forecast Error Variance Decomposition terhadap Shock CDS

\begin{tabular}{c|cccccccc}
\hline Periode & S.E. & CDS & IHSG & BI_Rate & CAD_DEV & $\begin{array}{c}\text { PDB_ } \\
\text { Growth }\end{array}$ & Kurs & Yield \\
\hline $\mathbf{1}$ & 0.077893 & 100.0000 & 0.000000 & 0.000000 & 0.000000 & 0.000000 & 0.00000 & 0.00000 \\
$\mathbf{2}$ & 0.101440 & 96.32435 & 2.628919 & 0.081820 & 0.433504 & 0.083692 & 0.44624 & 0.00147 \\
$\mathbf{5}$ & 0.133004 & 85.72968 & 6.281850 & 0.302116 & 0.705332 & 4.489107 & 1.74465 & 0.74726 \\
$\mathbf{1 0}$ & 0.161069 & 77.04262 & 5.860788 & 0.684785 & 6.336818 & 4.512351 & 1.40636 & 4.15627 \\
$\mathbf{1 5}$ & 0.176379 & 68.19774 & 6.315665 & 2.832521 & 9.812186 & 7.148314 & 1.55754 & 4.13603 \\
$\mathbf{2 0}$ & 0.183465 & 63.31198 & 8.090508 & 4.801747 & 10.12349 & 7.198066 & 1.80766 & 4.66654 \\
$\mathbf{2 5}$ & 0.187858 & 61.72033 & 9.372757 & 5.128761 & 9.819877 & 7.476804 & 1.73287 & 4.74860 \\
$\mathbf{3 0}$ & 0.189481 & 61.65484 & 9.404636 & 5.156248 & 9.682391 & 7.501504 & 1.76288 & 4.83749 \\
$\mathbf{3 5}$ & 0.191177 & 60.87186 & 9.710743 & 5.544237 & 9.526919 & 7.400253 & 1.75202 & 5.19396 \\
$\mathbf{4 0}$ & 0.193147 & 59.67501 & 10.90568 & 5.861191 & 9.343729 & 7.294358 & 1.75240 & 5.16763 \\
\hline \multicolumn{7}{l}{ Sumber Bloomberg, Bank Indonesia dan Badan Pusat Statistik(BPS), (2015) }
\end{tabular}

Berdasarkan Tabel 6 menjelaskan tentang forecast error variance decomposition (FEVD) dari kejutan (shock) variabel CDS, yaitu Pada periode (bulan) pertama, variasi shock credit default swap (CDS) yang bersumber dari dirinya mencapai $100 \%$ dan kemudian terus menurun hingga mencapai 59,68\% pada bulan ke-40. Dengan kata lain kontribusi FEVD shock credit default swap (CDS) signifikan terhadap kejutan (shock) variabel credit default swap (CDS) itu sendiri karena pengaruhnya lebih besar sampai pada periode ke-40.

Tabel 7. Forecast Error Variance Decomposition IHSG

\begin{tabular}{c|cccccccc}
\hline Periode & S.E. & CDS & IHSG & BI_Rate & CAD_DEV & $\begin{array}{c}\text { PDB_ } \\
\text { Growth }\end{array}$ & Kurs & Yield \\
\hline 1 & 0.024809 & 31.2048 & 68.7952 & 0.000000 & 0.000000 & 0.000000 & 0.00000 & 0.00000 \\
2 & 0.039565 & 36.4753 & 59.8246 & 0.016363 & 1.494279 & 1.447744 & 0.39292 & 0.34883 \\
5 & 0.064393 & 34.2400 & 57.8848 & 0.654143 & 0.700177 & 4.948741 & 0.35132 & 1.22084 \\
10 & 0.090828 & 33.8161 & 43.2410 & 0.757686 & 5.383043 & 4.746329 & 1.43402 & 10.6218 \\
15 & 0.106129 & 34.7867 & 36.6463 & 0.823932 & 9.794403 & 4.987124 & 1.18928 & 11.7722 \\
20 & 0.111787 & 34.2363 & 35.2135 & 1.677366 & 12.15853 & 4.728737 & 1.20945 & 10.7761 \\
25 & 0.114265 & 33.1601 & 34.5295 & 2.180116 & 13.53988 & 5.072554 & 1.16369 & 10.3541 \\
30 & 0.116541 & 31.9946 & 34.4988 & 2.134568 & 14.42193 & 5.161123 & 1.20671 & 10.5822 \\
35 & 0.120320 & 30.1753 & 35.1495 & 2.169874 & 14.81475 & 5.099145 & 1.22456 & 11.3668 \\
40 & 0.124550 & 28.3852 & 37.1247 & 2.281207 & 14.66649 & 4.846149 & 1.15144 & 11.5447 \\
\hline
\end{tabular}

Sumber: Bloomberg, Bank Indonesia dan Badan Pusat Statistik(BPS), (2015)

Berdasarkan Tabel 7. tentang forecast error variance decomposition dari variabel IHSG. Hasil forecast error variance decomposition (FEVD) dari variabel IHSG diperoleh hasil yang menarik, dimana pengaruh shock CDS mampu menjelaskan IHSG sebesar $31.20 \%$ pada periode pertama, selanjutnya mengalami penurunan sampai pada periode ke-40 yaitu sebesar $28.39 \%$ dan berfluktuatif sampai pada periode terakhir. Secara keseluruhan FEVD IHSG dalam jangka panjang signifikan terhadap shock pada 
variabel credit default swap (CDS) karena pengaruhnya sangat besar sampai pada periode ke-40.

Tabel 8. Forecast Error Variance Decomposition BI Rate

\begin{tabular}{c|cccccccc}
\hline Periode & S.E. & CDS & IHSG & BI_Rate & CAD_DEV & $\begin{array}{c}\text { PDB_ } \\
\text { Growth }\end{array}$ & Kurs & Yield \\
\hline 1 & 0.001578 & 0.23376 & 11.7019 & 88.06426 & 0.000000 & 0.000000 & 0.00000 & 0.00000 \\
2 & 0.002869 & 2.40014 & 28.6900 & 65.56605 & 0.023391 & 0.007654 & 1.02963 & 2.28309 \\
5 & 0.006966 & 3.38849 & 38.8531 & 34.62283 & 1.914723 & 2.095651 & 0.54603 & 18.5791 \\
10 & 0.011659 & 5.97002 & 42.4957 & 25.44983 & 4.345370 & 1.476474 & 0.50636 & 19.7562 \\
15 & 0.014009 & 5.88161 & 50.9211 & 20.77335 & 3.501555 & 1.436294 & 3.09554 & 14.3905 \\
20 & 0.015439 & 5.29873 & 52.2282 & 17.88477 & 2.988871 & 3.067489 & 4.29711 & 14.2348 \\
25 & 0.016143 & 5.35433 & 52.3993 & 17.29205 & 2.869651 & 4.030288 & 4.19559 & 13.8587 \\
30 & 0.016619 & 6.09556 & 52.1514 & 17.51352 & 2.745976 & 4.289820 & 3.96154 & 13.2421 \\
35 & 0.016953 & 6.81852 & 51.9457 & 17.44794 & 2.786978 & 4.173053 & 3.82014 & 13.0076 \\
40 & 0.017084 & 7.08437 & 52.0496 & 17.27608 & 2.812298 & 4.123524 & 3.81930 & 12.8347 \\
\hline
\end{tabular}

Sumber: Bloomberg, Bank Indonesia dan Badan Pusat Statistik(BPS), (2015)

Berdasarkan Tabel 8. menjelaskan perkiraan kesalahan varians dekomposisi variabel BI rate. Hasil forecast error variance decomposition (FEVD) dari variabel BI Rate diperoleh hasil yang berbeda, dimana pengaruh shock CDS mampu menjelaskan BI Rate sebesar $0.23 \%$ sangat kecil pada periode pertama, selanjutnya terus mengalami peningkatan sampai pada periode ke-40 yaitu sebesar $7.08 \%$. Meskipun peranannya kecil namun menunjukkan kecenderungan yang meningkat. Secara keseluruhan FEVD BI Rate dalam jangka panjang tidak signifikan menjelaskan terhadap shock pada variabel credit default swap (CDS) karena pengaruhnya sangat kecil sampai pada periode ke-40.

Tabel 9. Forecast Error Variance Decomposition Cadangan Devisa

\begin{tabular}{c|cccccccc}
\hline Periode & S.E. & CDS & IHSG & BI_Rate & CAD_DEV & $\begin{array}{c}\text { PDB__ } \\
\text { Growth }\end{array}$ & Kurs & Yield \\
\hline 1 & 0.026129 & 0.346791 & 6.42221 & 0.690424 & 92.54057 & 0.000000 & 0.00000 & 0.00000 \\
2 & 0.033277 & 0.886147 & 9.75945 & 0.753542 & 82.75049 & 3.598919 & 2.22427 & 0.02716 \\
5 & 0.051807 & 20.86845 & 17.2583 & 0.519625 & 45.35751 & 8.757416 & 4.97556 & 2.26307 \\
10 & 0.069541 & 16.51680 & 37.3483 & 2.871809 & 26.87933 & 7.120727 & 6.55539 & 2.70762 \\
15 & 0.079477 & 13.66541 & 40.3221 & 5.498671 & 24.45699 & 7.044460 & 5.39625 & 3.61603 \\
20 & 0.089389 & 11.37776 & 47.0052 & 7.341373 & 19.70803 & 6.054759 & 5.59824 & 2.91459 \\
25 & 0.097551 & 9.915713 & 50.9622 & 8.541050 & 16.65043 & 6.246427 & 5.21788 & 2.46625 \\
30 & 0.103932 & 9.284274 & 53.5751 & 9.420629 & 14.67029 & 6.008141 & 4.86155 & 2.17992 \\
35 & 0.108879 & 9.283278 & 54.7798 & 9.946296 & 13.38747 & 6.090300 & 4.50705 & 2.00573 \\
40 & 0.112091 & 9.617456 & 55.4578 & 10.08852 & 12.67000 & 5.952008 & 4.29008 & 1.92404 \\
\hline
\end{tabular}

Sumber: Bloomberg, Bank Indonesia dan Badan Pusat Statistik(BPS), (2015)

Tabel 9 menjelaskan tentang forecast error variance decomposition dari variabel cadangan devisa. Hasil forecast error variance decomposition (FEVD) dari variabel cadangan devisa peroleh hasil yang berbeda, dimana pengaruh shock CDS mampu menjelaskan cadangan devisa sebesar $0.35 \%$ sangat kecil pada periode pertama, selanjutnya pada periode ke-40 yaitu sebesar $9.62 \%$ dan cenderung berfluktuatif sampai periode terakhir. Dalam jangka panjang FEVD variabel cadangan devisa tidak 
signifikan terhadap shock pada variabel credit default swap (CDS) karena pengaruhnya sangat kecil sampai pada periode ke-40.

Tabel 10. Forecast Error Variance Decomposition PDB Growth

\begin{tabular}{c|cccccccc}
\hline Periode & S.E. & CDS & IHSG & BI_Rate & CAD_DEV & $\begin{array}{c}\text { PDB__ } \\
\text { Growth }\end{array}$ & Kurs & Yield \\
\hline 1 & 0.50177 & 0.18785 & 4.79813 & 0.266118 & 0.571746 & 94.17616 & 0.00000 & 0.00000 \\
2 & 0.62956 & 0.36535 & 3.37295 & 0.170977 & 2.307893 & 93.73047 & 0.00131 & 0.05106 \\
5 & 0.77035 & 1.59389 & 8.04169 & 0.702198 & 5.321633 & 82.47100 & 1.78954 & 0.08005 \\
10 & 0.82952 & 1.92903 & 7.63685 & 1.093338 & 6.337431 & 79.04970 & 2.96002 & 0.99364 \\
15 & 0.85442 & 1.93084 & 7.36518 & 1.062888 & 6.289817 & 79.09716 & 3.11874 & 1.13538 \\
20 & 0.86072 & 1.91448 & 7.32158 & 1.076599 & 6.265360 & 79.03019 & 3.09895 & 1.29284 \\
25 & 0.86237 & 1.91658 & 7.30144 & 1.079093 & 6.267576 & 79.02109 & 3.10392 & 1.31031 \\
30 & 0.86302 & 1.91713 & 7.29163 & 1.093765 & 6.265801 & 79.00615 & 3.10410 & 1.32143 \\
35 & 0.86328 & 1.91698 & 7.29885 & 1.108521 & 6.264746 & 78.97858 & 3.10519 & 1.32713 \\
40 & 0.86349 & 1.91645 & 7.30747 & 1.116161 & 6.264347 & 78.95711 & 3.10832 & 1.33014 \\
\hline
\end{tabular}

Sumber: Bloomberg, Bank Indonesia dan Badan Pusat Statistik(BPS), (2015)

Berdasarkan Tabel 10 menjelaskan tentang forecast error variance decomposition dari variabel PDB growth. Hasil forecast error variance decomposition (FEVD) dari variabel $P D B$ growth diperoleh hasil yang berbeda, dimana pengaruh shock CDS mampu menjelaskan $P D B$ growth sebesar $0.19 \%$ sangat kecil dibandingkan dengan variabel yang lain pada periode pertama, selanjutnya pada periode ke-40 yaitu sebesar $1.92 \%$, cenderung berfluktuatif dan pengaruhnya hampir sama sampai periode terakhir. Dalam jangka panjang FEVD PDB growth terhadap kejutan atau shock pada variabel credit default swap (CDS) sangat lemah dan tidak signifikan.

Tabel 11. Forecast Error Variance Decomposition Kurs

\begin{tabular}{c|cccccccc}
\hline Periode & S.E. & CDS & IHSG & BI_Rate & CAD_DEV & $\begin{array}{c}\text { PDB_ } \\
\text { Growth }\end{array}$ & Kurs & Yield \\
\hline 1 & 0.011064 & 24.9074 & 28.4189 & 0.289277 & 1.496531 & 0.008282 & 44.8796 & 0.00000 \\
2 & 0.017269 & 31.5576 & 36.2281 & 0.188498 & 1.330962 & 0.088934 & 30.4571 & 0.14881 \\
5 & 0.029222 & 29.5429 & 37.0326 & 0.565451 & 1.019095 & 10.25412 & 18.9658 & 2.61989 \\
10 & 0.039402 & 30.4909 & 33.2449 & 1.205373 & 1.824069 & 16.71933 & 14.9645 & 1.55087 \\
15 & 0.043732 & 31.7136 & 31.2108 & 1.511385 & 2.689941 & 13.95905 & 17.1485 & 1.76659 \\
20 & 0.046648 & 29.3968 & 29.5974 & 2.010678 & 2.652408 & 13.64157 & 19.4190 & 3.28207 \\
25 & 0.048488 & 27.2579 & 28.4355 & 3.052581 & 2.497109 & 13.29170 & 20.5634 & 4.90180 \\
30 & 0.050309 & 25.3923 & 27.4071 & 4.880633 & 2.579951 & 13.37124 & 20.5564 & 5.81251 \\
35 & 0.052033 & 23.8194 & 26.6829 & 6.923554 & 2.934253 & 13.47452 & 20.0492 & 6.11624 \\
40 & 0.053622 & 22.4608 & 25.9942 & 8.411964 & 3.519367 & 13.71421 & 19.4828 & 6.41669 \\
\hline
\end{tabular}

Sumber: Bloomberg, Bank Indonesia dan Badan Pusat Statistik(BPS), (2015)

Berdasarkan Tabel 11 menjelaskan tentang forecast error variance decomposition dari variabel kurs. Hasil forecast error variance decomposition (FEVD) dari variabel Kurs peroleh hasil yang berbeda, dimana pengaruh shock CDS mampu menjelaskan kurs sebesar $24.90 \%$ pada periode pertama, selanjutnya pada periode ke-40 yaitu 
sebesar $22.46 \%$ dan cenderung berfluktuatif sampai periode terakhir. Dalam jangka panjang FEVD kurs signifikan terhadap kejutan (shock) credit default swap (CDS) sangat besar jika dibandingkan dengan variabel lainnya.

Table 12. Forecast Error Variance Decomposition Bond Yield

\begin{tabular}{c|cccccccc}
\hline Periode & S.E. & CDS & IHSG & BI_Rate & CAD_DEV & $\begin{array}{c}\text { PDB_ } \\
\text { Growth }\end{array}$ & Kurs & Yield \\
\hline 1 & 0.006974 & 16.4053 & 41.5472 & 0.196480 & 0.166831 & 1.437392 & 0.62916 & 39.6176 \\
2 & 0.010827 & 20.8005 & 40.1554 & 1.100654 & 0.074591 & 2.187204 & 0.57233 & 35.1093 \\
5 & 0.015017 & 25.3209 & 36.2166 & 1.166924 & 2.931521 & 6.297016 & 1.23911 & 26.8279 \\
10 & 0.019444 & 28.2782 & 32.4624 & 0.756243 & 8.214359 & 3.855851 & 2.67714 & 23.7558 \\
15 & 0.021880 & 28.2961 & 32.5581 & 0.906160 & 9.472754 & 3.288412 & 5.98277 & 19.4958 \\
20 & 0.022966 & 26.8093 & 32.9179 & 0.892932 & 9.636224 & 3.369548 & 7.64321 & 18.7309 \\
25 & 0.023654 & 25.5951 & 34.0633 & 1.576911 & 9.627670 & 3.319491 & 8.03531 & 17.7822 \\
30 & 0.024628 & 23.8231 & 35.8932 & 3.389850 & 9.222437 & 3.272835 & 7.91383 & 16.4848 \\
35 & 0.025761 & 21.9171 & 38.2658 & 5.128660 & 8.513404 & 3.261262 & 7.82065 & 15.0931 \\
40 & 0.026817 & 20.3245 & 40.1909 & 6.237362 & 7.872105 & 3.555969 & 7.76743 & 14.0518 \\
\hline
\end{tabular}

Sumber: Bloomberg, Bank Indonesia dan Badan Pusat Statistik(BPS), (2015)

Berdasarkan Tabel 12 menjelaskan tentang forecast error variance decomposition dari variabel yield. Hasil forecast error variance decomposition (FEVD) dari variabel yield peroleh hasil yang berbeda, dimana pengaruh shock CDS mampu menjelaskan yield sebesar $16.40 \%$ pada periode pertama, selanjutnya pada periode ke-40 yaitu sebesar $22.46 \%$ dan cenderung berfluktuatif sampai periode terakhir. Dalam jangka panjang FEVD yield signifikan terhadap kejutan (shock) credit default swap (CDS) jika dibandingkan dengan variabel lainnya.

\section{KESIMPULAN DAN SARAN}

\section{Kesimpulan}

Dari hasil estimasi impulse response function (IRF) terlihat bahwa respon credit default swap (CDS) lebih cepat dipengaruhi oleh sektor perbankan terlebih dahulu kemudian sektor riil. Fenomena ini menggambarkan jika terjadi gejolak ekonomi global maka kejutan (shock) secara cepat akan mempengaruhi IHSG, BI rate, kurs dan yield jika dibandingkan dengan variabel-variabel cadangan devisa dan PDB growth. Selain itu, diperoleh hasil bahwa sektor perbankan yang relatif panjang dalam mencapai keseimbangannya artinya membutuhkan waktu yang lama untuk proses pemulihan sedangkan pada pertumbuhan ekonomi membutuhkan waktu yang relatif singkat.

Hasil forecast error dari credit default swap (CDS) sesuai dengan urutan pengaruh yang terbesar adalah CDS itu sendiri sedangkan variabel lain berturut-turut adalah, IHSG, kurs, yield, cadangan devisa, BI Rate dan PDB growth. Dengan demikian kontribusi terbesar terhadap penurunan credit default swap (CDS) adalah perbankan seperti IHSG, kurs dan yield.

\section{Saran}

Pemerintah harus mampu mempertahankan IHSG BI rate, cadangan devisa, nilai tukar dan hasil, tidak menempatkan shock yang mengakibatkan credit default swap (CDS) yang tinggi. Kedua, memperkuat fondasi ekonomi di sektor riil seperti meningkatkan cadangan devisa dalam mengantisipasi kejutan negatif dalam hal krisis tiba-tiba seperti yang sering terjadi melalui sektor perbankan.

Disertai dengan kerja sama antara lembaga keuangan dalam hal ini, Bank Indonesia (BI) dan Otoritas Jasa Keuangan, hubungannya dengan penentuan tingkat 
kebijakan penetapan tingkat, nilai tukar BI dan hasil, kemudian, meningkatkan koordinasi kerjasama antara lembaga keuangan , universitas, lembaga dan penilaian ekonomi dari para pemangku kepentingan dalam merumuskan dan memecahkan masalah dengan pengambilan keputusan dan kebijakan yang lebih tepat. Kemudian, didorong oleh infrastruktur seperti modal, infrastruktur yang baik dalam meningkatkan iklim investasi dan menarik investor. Hal yang paling penting adalah bahwa pemerintah harus menjaga agar tetap persepsi investor yang positif dari ekspektasi pasar modal Indonesia.

\section{DAFTAR PUSTAKA}

Aini, D.N. (2012). Analisis interest rate, stock return dan implied volatility terhadap Credit Default Swap (CDS) di Indonesia, Fakultas Ilmu Sosial dan Politik, Universitas Indonesia: Depok.

Ajija,S.R., Sari, D.W., Setianto, R,H., \& Primanti, M,R. (2011). Cara cerdas menguasai Eviews. Salemba Empat: Jakarta.

Alexander, C., \& Kaeck, A. (2007). Rengime dependent determinants of credit default swap spreads. Journal of Banking \& Finance, 32, 1008-1021.

Anggraini, D. (2014). Pengaruh makro ekonomi terhadap credit default swap (CDS). Thesis. Manajemen Universitas Gadjah Mada: Yogyakarta

Ariefianto,M.D.,\& Soepomo.S. (2011). Analisa sovereign risk negara berkembang temuan dari prilaku premi Credit Default Swap. Buletin Ekonomi Moneter dan Perbankan.

Arrufat, J.L., Cafferata A.M. D., Figueras ,A.J.,\& Utrera, G.E.(1999). Hysteresis and structural breaks.in regional unemployment Argentina 1980-1998. Anales de la Asociación Argentina de Economía Política. XXXIV Reunión Anual: Rosario,

C.Clani, M., Chile, B.C.De. (2013). Spillover of credit default swap market.

Calice, G., Loannnidis, C.(2009). An empirical analysis of the impact of the credit default swap index market on large complex financial institutions.

Eyssell, T., Fung, H.G., \& Zhang, G. (2010). Determinants and price discovery of China soverign credit default swap.

Ginting, R.Y., \& Suwardi, E. (2015). Effect of interest rate, inflantion and bond liquidity on yield to marturity (YTM) of conventiona corporate bonds in Indonesia stock exchange, Balancing Indonesia Economy.

Goldstein, M., Graciela, L. K., \& Carmen, R. (2000). Assessing financial vulnerability:an early warning system for emerging markets. Institute for international economics, Washington DC: USA

Gujarati \& Porter. (2009). Dasar-dasar ekonometrika. Salemba Empat: Jakarta

Hadi, Y.S. (2013). Analisis Vector Auto Regression (VAR) terhadap Korelasi antara Pendapatan Nasional dan Investasi Pemerintah di Indonesia, 1983/19841999/2000. Jurnal Keuangan dan Moneter, 6(2). 19-39

Hill, R.C., Griffiths, W, E., \& Lim, G, C. (2011). Principles of econometrics" $4^{\text {rd }}$ Edition.758p. University of Melbourne.

Imansyah, M.H. (2009). Krisis keuangan di Indonesia dapatkah diramalkan?”. PT.Elex Media Komputindo, Gramedia: Jakarta

International Monetary Fund.(2013).Global financial stability report on April 2013 on Chapter 2: A New Look at The Role of Sovereign Credit Default Swap.

Ismailescue, L., \& Philips, B. (2015). Credit default swap and mareket for soverign debt". Journal of Banking \& Finance. 52(C), 43-61. 
Jacobs, P., Abubakar, A., \& Siallagan, T, E.(2011). Analisis prilaku indikator debt market. Buletin Ekonomi Moneter dan Perbankan.

Karlson, E. \& Willebrand, N.(2009). Examining the determinan of credit default swap spread. Journal of Euopean Financial Institution.

Kim, Suk-Joong., Salem, L., \& Wu, E. (2015). The role of macroeconomic news in sovereign CDS market:domestic and spillover news effects from the U.S., the Eurozone dan China. Journal of financial stability Elsevier, 18(C), 208-224.

Longstaff, F.A., \& Mayers, B. (2009). An analysis of CDO equity. Journal of Economic, 29(2), 119-135.

Nomura. (2004). Fixed income research. Credit Default Swaps Primer: Japan.

Okky, D., \& Setiawan. (2012). Permodalan indeks harga saham gabungan (IHSG), kurs dan harga minyak dunia dengan pendekatan vector autoregressive. Journal Sains dan Seni ITS, 1(1), 87-.92

Parrado, E. (2001). Effect of foreign and domestic monetary policy in small open economy: case of chile. Banco Central de Chile Documentos de Trabajo. International Monetary Fund.

Pindyck, R.S.(1991). Irreversibility, uncertainty and investment. Journal of Economic Literature, 29(3): 1110-1148.

Salvatore, D.(1994). Ekonomi internasional, Edisi Ketiga. Penerbit Erlangga: Jakarta.

Sims, C.(1980). Macroeconomics and reality. Econometrica. 48(1),1-48, DOI:10.2307/1912017

Tampubolon,I.K., \& Hidayat, P. (2011). Analisis souverign risk di negara-negara ASEAN. Jurnal Ekonomi dan Keuangan, 1(12).1-14

Tandelilin, E. (2001). Analisis investasi dan manajemen portofiolio”, edisi pertama, BPFE UGM: Yogyakarta.

Wardhana,D. (2005). Analisis uji komplementaris mckinnon terhadap liberalisasi keuangan indonesia periode 1970-2003: pendekatan vector error correction model. Skripsi S1 FEB UGM: Yogyakarta

Whetten, M., Adelson M., \& Van, B. (2004). Credit Default Swap: A primer. Nomura Fixed income research.

Zivot, E., \& Andrews, D.W.K .(1992). Future evidence on the great crash, the oil price shock, and the unit root hypothesis. Journal of Business \& Economic Statistics. 10(3), 251-270, DOI: 10.1080/07350015.1992.10509904 